\title{
Variability of expression of oral-facial-digital syndrome type I in 15 Saudi girls: Why is there a high rate of median cleft lip in the phenotype?
}

\author{
Mohammad M Al-Qattan MBBS, K Javed MD
}

\begin{abstract}
MM Al-Qattan, K Javed. Variability of expression of oral-facial- digital syndrome type I in 15 Saudi girls: Why is there a high rate of median cleft lip in the phenotype? Plast Surg 2014;22(4):229-232.
\end{abstract}

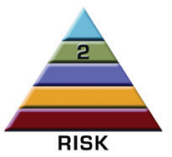

BACKGROUND: It is well known that the incidence of nonsyndromal cleft lip and palate varies greatly according to ancestry: 0.3 to 0.4 per 1000 live births in blacks, one in 1000 in Caucasians, and two in 1000 in Asians and individuals from the central province of Saudi Arabia. Median cleft lip is a variable feature in oral-facial-digital syndrome type I (OFD-I). OBJECTIVE: To test the hypothesis that genetic factors may determine the lip phenotype in OFD-I patients.

METHODS: A study involving 15 Saudi girls (from the central province of Saudi Arabia) with OFD-I showed a high rate $(93.3 \%)$ of median cleft lip and palate. This rate in OFD-I patients is known to range from $33 \%$ to $56 \%$ in Caucasians and also known to be very low in blacks. The authors compared the rate of median cleft lip with or without cleft palate in the Arabian series (93.3\%) with the rate in Caucasians and blacks.

RESULTS: The difference in median cleft lip with or without cleft palate among the three groups was significant.

CONCLUSION: This supports the hypothesis that ancestral genetic factors may determine the lip phenotype in OFD-I patients.

Key Words: Arabs; Expression; Oral-facial-digital; Saudi

$\mathrm{T}$ he epidemiology of cleft lip and palate has been extensively studied in various populations. The incidence of isolated cleft palate ( 0.3 to 0.5 per 1000 live births) is similar in most populations. In contrast, the incidence of nonsyndromal cleft lip and palate varies greatly, from 0.3 to 0.4 per 1000 in blacks to 1.5 to 2 per 1000 in Asians. The incidence of cleft lip with or without cleft palate in Caucasians is approximately one per 1000 live births (1-6).

Oral-facial-digital syndrome type I (OFD-I) is inherited as an $\mathrm{X}$-linked dominant trait and is lethal in males. Incidence among Caucasians is approximately one per 50,000 live births (7). Its main clinical features include a partial median cleft or median pseudocleft of the upper lip, cleft palate, bifid/lobulated tongue, lingual hamartoma, dental abnormalities, and abnormalities of the digits of hands/feet including brachydactyly, clinodactyly, syndactyly and, more rarely, polydactyly $(7,8)$. Other features include epicanthus, hypertelorism, brittle scalp hair/alopecia, milia of face/ears, hypoplasia of nasal ala, polycystic kidneys, intellectual disability and central nervous system malformations $(9,10)$. The syndrome is caused by mutations in the CXORF5 gene $(11,12)$.

In 1991, Salinas et al (13) reviewed the literature on the clinical features of OFD-I in blacks. There were a total of eight cases: six were reported by Salinas et al (13) and another two cases were previously reported by Harrod et al (14) and Pruzansky et al (15). In these eight black females with OFD-I, 25\% had isolated cleft palate and none had median cleft or pseudocleft of the upper lip. It is well known that, on average, $45 \%$ of Caucasians with OFD-I have a median cleft/pseudocleft of the upper lip (7). These findings suggest that ancestral genetic

\author{
La variabilité de l'expression du syndrome \\ orofaciodigital de type I chez 15 fillettes \\ saoudiennes : pourquoi le phénotype s'associe-t-il à \\ un taux élevé de fente labiale médiane?
}

\begin{abstract}
HISTORIQUE : Il est bien connu que l'incidence de fente labiale et palatine non syndromique varie considérablement selon l'ascendance : 0,3 à 0,4 cas sur 1000 naissances vivantes chez les Noirs, un cas sur 1000 chez les Blancs et deux cas sur 1000 chez les Asiatiques et les personnes de la province centrale d'Arabie saoudite. La fente labiale médiane est une caractéristique variable du syndrome orofaciodigital de type I (OFD-I).

OBJECTIF : Vérifier l'hypothèse selon laquelle des facteurs génétiques peuvent déterminer le phénotype labial chez des patients atteints de l'OFD-I. MÉTHODOLOGIE : Une étude auprès de 15 fillettes saoudiennes (de la province centrale d'Arabie saoudite) atteintes de l'OFD-I a révélé un taux élevé $(93,3 \%)$ de fente labiale et palatine médiane. Chez les patientes atteintes de l'OFD, on sait que ce taux varie entre $33 \%$ et $56 \%$ chez les Blancs et qu'il est très faible chez les Noirs. Les auteurs ont comparé le taux de fente labiale médiane accompagnée ou non d'une fente palatine dans la série de fillettes arabes $(93,3 \%)$ à celui des Blancs et des Noirs.

RÉSULTATS : Dans les trois groupes, les fentes labiales médianes accompagnées ou non d'une fente palatine sont très différentes.

CONCLUSION : Les résultats appuient l'hypothèse selon laquelle les facteurs génétiques liés à l'ascendance détermineraient le phénotype labial chez les patients atteints de l'OFD-I.
\end{abstract}

factors may protect lip development in blacks with OFD-I (because the incidence of nonsyndromal cleft lip and palate in blacks is much lower than in Caucasians). This theory could not be tested further because, for unknown reasons, OFD-I is extremely rare in Asians (16) and there have been no case series investigating OFD-I from the Far East to date. The incidence of clefts in the central province of Saudi Arabia is unusually high (2.19 per 1000 live births) (4). This may offer the opportunity to investigate the hypothesis proposed by Salinas et al (13). If the hypothesis is correct, the frequency of cleft lip and palate in OFD-I syndrome patients from the central province of Saudi Arabia would be expected to be significantly higher than in Caucasians and blacks.

The current study investigated the clinical features of OFD-I syndrome in a group of 15 Saudi patients from the central province of Saudi Arabia, with particular emphasis on comparing the frequency of clefts among Saudi, black and Caucasian patients with OFD-I syndrome.

\section{METHODS}

The authors have been practicing in the central province of Saudi Arabia since 1994. All native Saudi patients from the central province who were seen at three large government hospitals over the past 18 years (1994 to 2011) with the diagnosis of OFD-I were retrospectively reviewed. Sex, family history, clinical features and radiological investigations were reviewed. Particular attention was devoted to the presence of clefting, which was divided into two main groups: cleft lip and palate; and isolated cleft palate. Cleft lip included both median

Plastic Surgery Division, King Saud University and Plastic Surgery Division, King Faisal Specialist Hospital and Research Center, Riyadh,

Saudi Arabia

Correspondence: Dr MM Al-Qattan, PO Box 18097, Riyadh 11415, Saudi Arabia. E-mail moqattan@hotmail.com 
TABLE 1

Clinical features of 15 Saudi girls with oral-digital-facial type I syndrome

\begin{tabular}{|c|c|c|c|c|c|c|c|c|c|c|c|c|c|c|c|}
\hline \multirow[b]{2}{*}{ Clincal feature } & \multicolumn{15}{|c|}{ Patient } \\
\hline & 1 & 2 & 3 & 4 & 5 & 6 & 7 & 8 & 9 & 10 & 11 & 12 & 13 & 14 & 15 \\
\hline Family history & - & - & - & - & - & - & - & - & - & - & - & - & - & - & - \\
\hline Hypertelorism & - & - & + & - & + & + & - & + & - & + & + & + & + & - & - \\
\hline Epicanthus & - & - & - & - & - & - & - & - & - & + & - & - & + & - & - \\
\hline Hypoplasia of the nasal ala & + & - & + & + & - & + & + & + & + & - & + & - & + & + & - \\
\hline Median 'pseudo' cleft lip & + & - & + & - & + & + & - & + & - & - & + & + & + & + & - \\
\hline Median cleft lip & - & + & - & - & - & - & - & - & + & + & - & - & - & - & + \\
\hline Median cleft lip and palate & - & - & - & - & - & - & + & - & - & - & - & - & - & - & - \\
\hline Isolated cleft palate & - & - & - & + & - & - & - & - & - & - & - & - & - & - & - \\
\hline Bifid/lobulated tongue & + & + & + & + & + & + & + & + & + & + & + & + & + & + & - \\
\hline Lingual hamartoma & - & + & + & + & - & - & - & + & + & - & + & + & + & - & + \\
\hline Brittle hair/alopecia & - & + & - & + & - & + & + & + & + & + & - & + & - & + & + \\
\hline Teeth abnormalities & + & - & + & + & + & + & + & + & - & + & + & + & - & + & + \\
\hline Brain abnormalities & - & + & NA & NA & NA & - & + & NA & + & NA & NA & NA & - & - & + \\
\hline \multicolumn{16}{|l|}{ Hands } \\
\hline Brachydactyly/clinodactyly & + & - & - & + & + & - & + & + & + & + & + & - & + & + & + \\
\hline Syndactyly & - & - & - & - & + & - & + & + & - & - & + & - & + & - & - \\
\hline Polydactyly & - & - & - & - & - & - & - & + & - & - & - & - & - & - & - \\
\hline \multicolumn{16}{|l|}{ Feet } \\
\hline Brachydactyly/clinodactyly & + & + & + & + & - & + & + & - & + & - & + & + & - & + & - \\
\hline Syndactyly & - & - & - & - & + & - & - & + & - & - & - & - & - & - & - \\
\hline Polydactyly & - & - & - & - & - & - & - & - & - & - & - & - & - & - & - \\
\hline
\end{tabular}

- Negative; + Positive; NA Not available (computed tomography/magnetic resonance imaging were not performed)

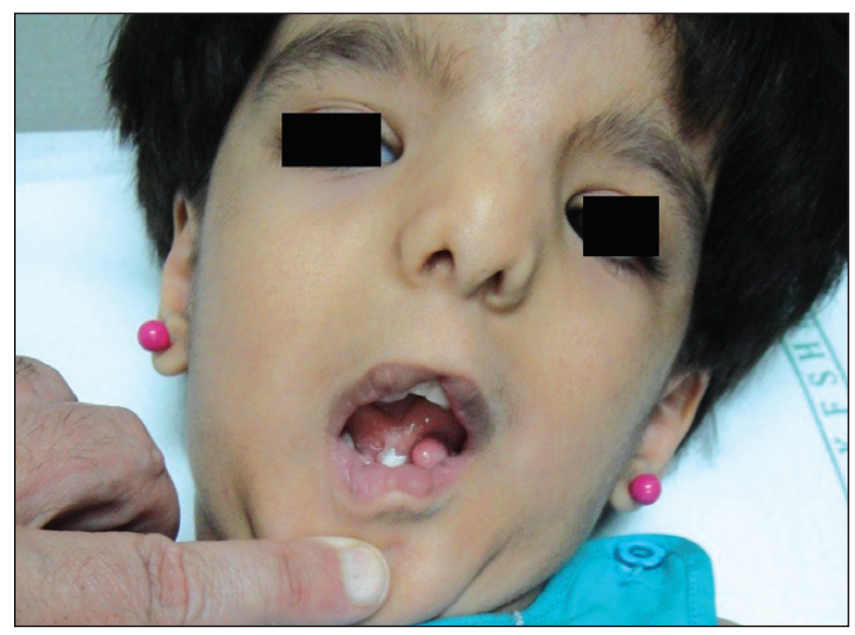

Figure 1) An example of a median mucosal cleft (also known as a pseudocleft). Note that the cleft does not extend to skin. Also note the epicanthus, the hypoplastic alae, the bifid tongue and the lingual hamartoma

cleft lip and median 'pseudocleft' lip. The median 'pseudocleft' lip is a common term used in the genetics literature and is used when the central tubercle of the upper lip is replaced by a mucosal cleft in the midline (Figure 1). In the plastic surgery literature, this is usually referred to as 'forme fruste' median cleft lip. The term 'median cleft lip' is used when the mucosal cleft extends to the skin of upper lip. Finally, the frequency of clefts in the present series was compared with the frequency of clefts in blacks (13-15) and Caucasians (7). Fisher's exact test was used to investigate differences among the groups; $\mathrm{P}<0.05$ was considered to be statistically significant.

\section{RESULTS}

A total of 15 patients (from 15 different families) were seen, all of whom were female. The mean age at presentation was two years (range one month to seven years). Family history was negative in all cases, suggesting a new mutation. Hypoplasia of the nasal ala (10 of 15 patients) was more commonly observed than hypertelorism (eight of 15 patients) and epicanthus (two of 15 patients). Fourteen of 15 patients had cleft lip and palate (nine median mucosal clefts, four median cleft lips extending to the skin edge only and one case had a median mucosal cleft with concurrent cleft of the soft palate). The remaining patient had an isolated cleft of the soft palate. Bifid and/or lobulated tongue was observed in 14 patients and lingual hamartomas in nine. Only eight patients underwent computed tomography/magnetic resonance imaging of the brain and, of these, four had abnormalities in the form of midline cysts. Brachydactyly and/or clinodactyly was a consistent feature in the hands and/or feet. Syndactyly was observed in five cases in the hands and two cases in the feet. Only one case of rudimentary thumb polydactyly was observed. The detailed features for every patient are shown in Table 1. The table does not include polycystic kidneys and intellectual disability because abdominal ultrasound was performed in only two patients (both were negative) and IQ testing was not performed in any of the patients. Similarly, the presence or absence of milia of the face was poorly documented in the charts.

A comparison of clefts in OFD-I among blacks, Caucasians and Saudi Arabians is shown in Table 2. The percentage of Saudi Arabians with cleft lip with or without cleft palate $(93.3 \%)$ was significantly higher than the percentage in Caucasians $(56.3 \%)$ and blacks $(0 \%)$. The percentage in blacks was also significantly lower than in Caucasians. However, there was no statistically significant difference when the percentages of isolated cleft palate were compared among the three groups. The P values are shown in Table 2.

\section{DISCUSSION}

Most articles regarding OFD-I are isolated case reports (16-25). Macca and Franco (26) recently reviewed the world literature on OFD-I and found that $32.6 \%$ of patients had median cleft lip/pseudocleft of the upper lip. Thauvin-Robinet et al (7) reviewed previously reported Caucasians cases and found that $45 \%$ of patients had cleft lip. One Brazilian series of 12 patients with OFD-I reported a higher rate of median cleft lip/pseudocleft of 50\% (27). We selected the Caucasian 
TABLE 2

\section{Clefting in oral-facial-digital type-I (OFD-I) syndrome among blacks, Caucasians and Saudi Arabians from the central province of Saudi Arabia}

\begin{tabular}{|c|c|c|c|c|}
\hline \multirow[b]{2}{*}{ Series } & \multirow[b]{2}{*}{ Patients, n } & \multirow[b]{2}{*}{ Sex } & \multicolumn{2}{|c|}{ Patients, n (\%) } \\
\hline & & & Cleft lip \pm palate & Isolated cleft palate \\
\hline $\begin{array}{l}\text { Black (Salinas et al [13], Harrod et al } \\
\text { [14], Pruzunsky et al [15]) }\end{array}$ & 8 & Female & $0(0)^{*}$ & $2(25)^{\dagger}$ \\
\hline Caucasian (Thauvin-Robinet et al [7]) & $16^{\ddagger}$ & Female & $9(56.3)^{\star}$ & $2(12.5)^{\dagger}$ \\
\hline Saudi Arabian (current series) & 15 & Female & $14(93.3)^{\star}$ & $1(6.7)^{\dagger}$ \\
\hline
\end{tabular}

*Using Fisher's exact test, the difference between the three groups was significant (blacks versus Caucasians: $P=0.009$; blacks versus Saudis: $P<0.0001$; Caucasians versus Saudis: $P=0.023) ;{ }^{\dagger}$ Using Fisher's exact test, there was no significant difference between the groups (blacks versus Caucasians: $P=0.407 ;$ blacks versus Saudis: $P=0.269$; Caucasians versus Saudis: $P=0.525)$; ${ }^{\ddagger}$ The original series of Thauvin-Robinet et al (7) had 25 cases, but nine were found negative for CXORF5 gene mutations. Hence, the table shows only 16 cases with the confirmed diagnosis of OFD-I syndrome

series (7) (all were French and Belgian females) with the highest reported rate of cleft lip (56.3\%) to avoid selection bias. The rate of median cleft lip/pseudocleft in our series $(93.3 \%)$ was significantly higher than the rate in the Caucasian series (56.3\%) (7) and the only available series of OFD-I in blacks (13) $(0 \%)$. The rate in blacks was also significantly lower than the rate in Caucasians (Table 2). This supports the hypothesis that the presence of the OFD-I gene only predisposes to median clefts of the upper lip and that racial genetic factors determine the phenotype.

Many believe that the occurrence of cleft lip with or without cleft palate depends on the additive effects of several minor mutant genes (ie, polygenic inheritance in which ancestry is playing a major role) as well as multiple environmental factors. The accumulation of these factors presumably can be tolerated by the developing fetus to a point (termed the 'threshold') beyond which there is risk for the cleft lip malformation (28). In other words, the variable 'threshold' for developing cleft lip in different ancestries determines the rate of cleft lip in the phenotype of OFD-I patients.

The upper lip develops from the neural ectoderm at the inferior aspect of the frontonasal process. The neural crest-derived mesenchyme condenses, forming the nasal pit, with the development of the medial and lateral nasal processes. The maxillary processes of the first branchial arch migrate toward the medial nasal processes (28). The lateral parts of the upper lip develop from the maxillary processes that meets the lateral surface of the medial processes. The medial processes also merge with each other toward the midline, forming the philtrum. Median cleft lip results from an error in this merging process in the midline (28). The cleft lip in all reported cases of OFD-I has been in the midline (Figure 2).

The OFD-I protein is present in the basal body of a slim microtubulebased organelle in the cell known as the 'primary cilium' (29). The primary cilium is involved in several cell functions/pathways. The cilium is the main area of the sonic hedgehog pathway in the neural tube and the limb buds, which explains the craniofacial and limb features of OFD-I patients. The OFD-I and other basal body proteins also enhance what is known as the 'WNT-planar cell polarity' pathway, which is responsible for proper tissue migration and intercalation of cells in the embryonic midline $(29,30)$. This explains the bifid tongue and the median cleft lip. The basal body of the primary cilium contains many proteins and a mutation of a single gene (OFD-I) will only 'weaken' the migration of the medial nasal processes toward the midline. This degree of weakening may not be sufficient to reach the threshold of developing a cleft lip in the black population, but is usually sufficient in the Saudi population.

ACKNOWLEDGEMENT: This work was supported by the College of Medicine Research Center, Deanship of Scientific Research, King Saud University, Saudi Arabia.

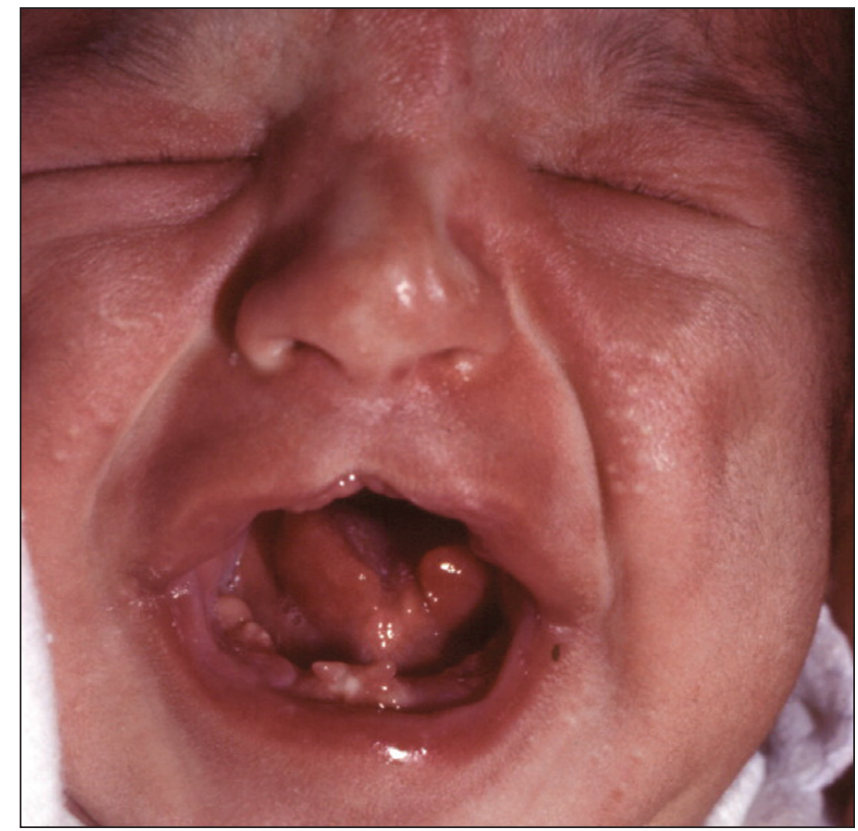

Figure 2) An example of a median cleft lip (extending to the skin). Note the bifid tongue. Milia of the face are also known to be a characteristic feature of oral-digital-facial type I syndrome

\section{REFERENCES}

1. Gundlach KK, Maus C. Epdemiological studies on the frequency of clefts in Europe and worldwide. J Craniomaxillofac Surg 2006;34:(Suppl 2):1-2.

2. Vanderas AP. Incidence of cleft lip, cleft palate and cleft lip and palate among races: A review. Cleft Palate J 1987;24:216-52.

3. Kromberg JG, Jenkis J. Common birth defects in South African blacks. S Afr Med J 1982;62:599-602.

4. Borkar AS, Mathur AK, Mahaluxmivala S. Epidemiology of facial clefts in the central province of Saudi Arabia. Br J Plast Surg 1993;46:673-5.

5. Beaty TH, Wang H, Hetmanski JB, et al. A case control study of non syndromic oral clefts in Maryland. Ann Epidemiol 2001;11:434-42.

6. Menegotto BG, Salzona FM. Epidemiology of oral clefts in a large South American sample. Cleft Palate Craniofac J 1991;28:373-6.

7. Thauvin-Robinet C, Cossee M, Cormier-Daire V, et al. Clinical, molecular, and genotype-phenotype correlation studies from 25 cases of oral-facial-digital syndrome type I: A French and Belgian collaborative study. J Med Genet 2006;43:54-61.

8. Anneren G, Arvidson B, Gustavson KH, Jorulf H, Carlsson G. Oro-facio-digital syndromes I and II: Radiological methods for diagnosis and the clinical variations. Clin Genet 1984;24:178-86.

9. Donnai D, Kerzin-Storrar K, Harris R. Familial orofacio-digital syndrome type I presenting as adult polycystic kidney disease. J Med Genet 1987;24:84-7. 
10. Odent S, Le Marec B, Toutain A, et al. Central nervous system malformations and early end-stage renal disease in oro-facio-digital syndrome type I: A review. Am J Med Genet 1998;75:389-94.

11. Ferrante MI, Giorgio G, Feather SA, et al. Identification of the gene for oral-facial-digital type I syndrome. Am J Hum Genet 2001;68:569-76

12. Ferrante MI, Barra A, Truong JP, et al. Characterization of OFDI/ OfdI genes on the human and mouse sex chromosomes and exclusion of OfdI for the XPI mouse mutant. Genomics 2003;81:560-9.

13. Salinas CF, Pai GS, Vera CL, et al. Variability of expression of the orofaciodigital syndrome type I in Black females: Six cases. Am J Med Genet 1991;38:574-82.

14. Harrod MJF, Stokes J, Peede LF, Goldstein JL. Polycystic kidney disease in patients with oral-facial-digital syndrome Type I. Clin Genet 1976;9:183-6.

15. Pruzansky S, Ruess A, Buzdygan D. Oral-facial-digital syndrome in a Negro female. Plast Reconstr Surg 1966;37:221-6.

16. King NM, Sonares AM. Oral-facial-digital syndrome, Type I: A case report. J Clin Pediatr Dent 2002;26:211-5.

17. Mihci E, Tacoy S, Ozbilim G, Franco B. Oral-facial-digital syndrome type I. Indian Pediatr 2007;44:854-6.

18. Al-Qattan MM, Hassanain JM. Classification of limb anomalies in oral-facial-digital syndromes. J Hand Surg Br 1997;22:250-2.

19. Al-Qattan MM. Cone-shaped epiphyses in the toes and trifurcation of the soft palate in oral-facial-digital syndrome type I. Br J Plast Surg 1998;51:476-9.

20. Morisawa T, Yagi M, Surono A, et al. Novel double-deletion mutations of the OFDI gene creating multiple novel transcripts. Hum Genet 2004;115:97-103.
21. Nishimura G, Kuwashima S, Kohno T, et al. Fetal polycystic kidney disease in oro-facio-digital syndrome type I. Pediatr Radiol 199;29:506-8.

22. Stapleton FB, Bernstein J, Keh G, Roy S, Wilroy RS. Cystic kidneys in a patient with oral-facial-digital syndrome type I. Am J Kidney Dis 1982;1:288-93.

23. Wood BP, Young LW, Townes. Cerebral abnormalities in the oralfacial-digital syndrome. Pediatr Radiol 1975;3:130-6.

24. Driva T, Franklin D, Crawford PJ. Variations in expression of oralfacial-digital syndrome (Type I): Report of two cases. Int J Pediatr Dent 2004;14:61-2.

25. Romero M, Franco B, del Pozo JS, Romance A. Buccal anomalies, cephalometric analysis and genetic study of two sisters with orofacial-digital syndrome type I. Cleft Palate Craniofac J 2007;44:660-6.

26. Macca M, Franco B. The molecular basis of oral-facial-digital syndrome, Type 1. Am J Med Genet (Part C) 2009;151:318-25.

27. Tigliani MM, Gomide MR, Carrara CF. Oral-facial-digital syndrome type I: Oral features in 12 patients submitted to clinical and radiographic examination. Cleft Palate Craniofac J 2010;47:162-6.

28. Melnik M. Cleft lip and cleft palate: Etiology and pathogenesis. In: Kernahan DA, Rosentein SW, eds. Cleft Lip and Palate. A System of Management. Baltimore: Williams and Wilkins, 1990:3-12.

29. Goetz SC, Anderson KV. The primary cilium: A signaling center during vertebrate development. Nature Rev 2010;11:331-44.

30. Cardenas-Rodriguez M, Badano JL. Ciliary biology: Understanding the cellular and genetic basis of human ciliopathies. Am J Med Genet (Part C) 2009;151:263-80. 